\title{
HERPES SIMPLEX CROSS INFECTION IN THE OPERATING ROOM
}

\author{
George G. DeYoung, M.D., A. W. Harrison, M.D., F.R.C.s.(c), \\ aNd James M. Shapley, M.D., C.M.*
}

Though it is becoming well documented in dermatological and bacteriological circles, herpetic infection of the finger due to cross contamination is still a relatively uncommon phenomenon. In 1959 Stern recognized it as a hazard to intensive care personnel. It is hoped that this report will increase the caution of anaesthesia staff who are exposed to infections from respiratory secretions.

\section{CASE Report}

Four days after intubating a patient with herpes simplex lesions about her mouth, an anaesthetic resident developed reddened, irritable areas on his index finger and thumb. The areas extended from a torn cuticle and small cut that were present at the time of exposure. The lesions progressed, invading subepidermally, and formed blisters (Fig. 1). Although Staph. Aureus was cultured from the
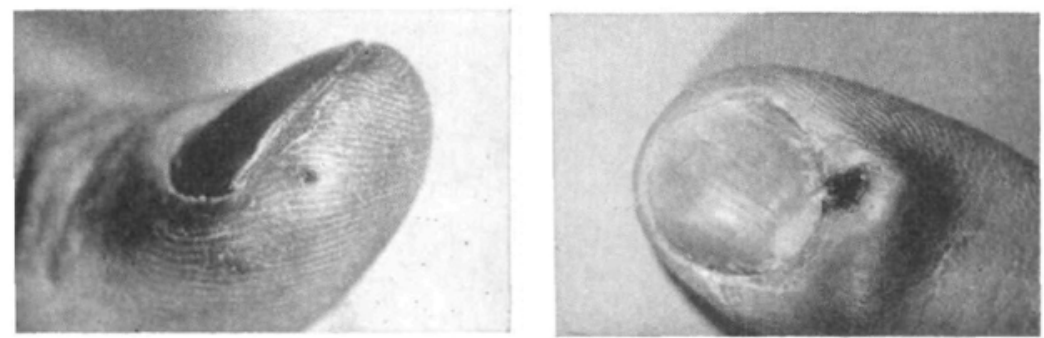

Figune 1. The herpetic lesions on the finger.

lesions and they began to appear pustular, the draining fluid remained clear and straw coloured. The resident was dismissed from the operating area and was placed on warm saline soaks.

During the next four days the lesion expanded, becoming very uncomfortable. The patient was placed on Tetracycline when an axillary lymph node became tender and palpable. On the eighth day after contact, nausea and vomiting with accompanying headache ensued for a 24-hour period, subsiding gradually over the next 48 hours. By the eleventh day the lesions had become violacious, swollen, and extremely painful. The lesion on the finger extended over the whole distal phalanx proximal to the nail. Both vesicles were opened to facilitate drainage and to alleviate pain. Further specimens were taken for bacteriological, mycological and virological studies. One sample was sent for electron microscopy and was found to contain large numbers of particles resembling herpes simplex virus. (See Fig. 2.) The lesions continued to drain straw clear, then turbid, fluid for the

Department of Anaesthesia and Department of Surgery, Sunnybrook Hospital and the University of Toronto.

Canad. Anaes. Soc. J., vol. 15, no. 4, July 1968 


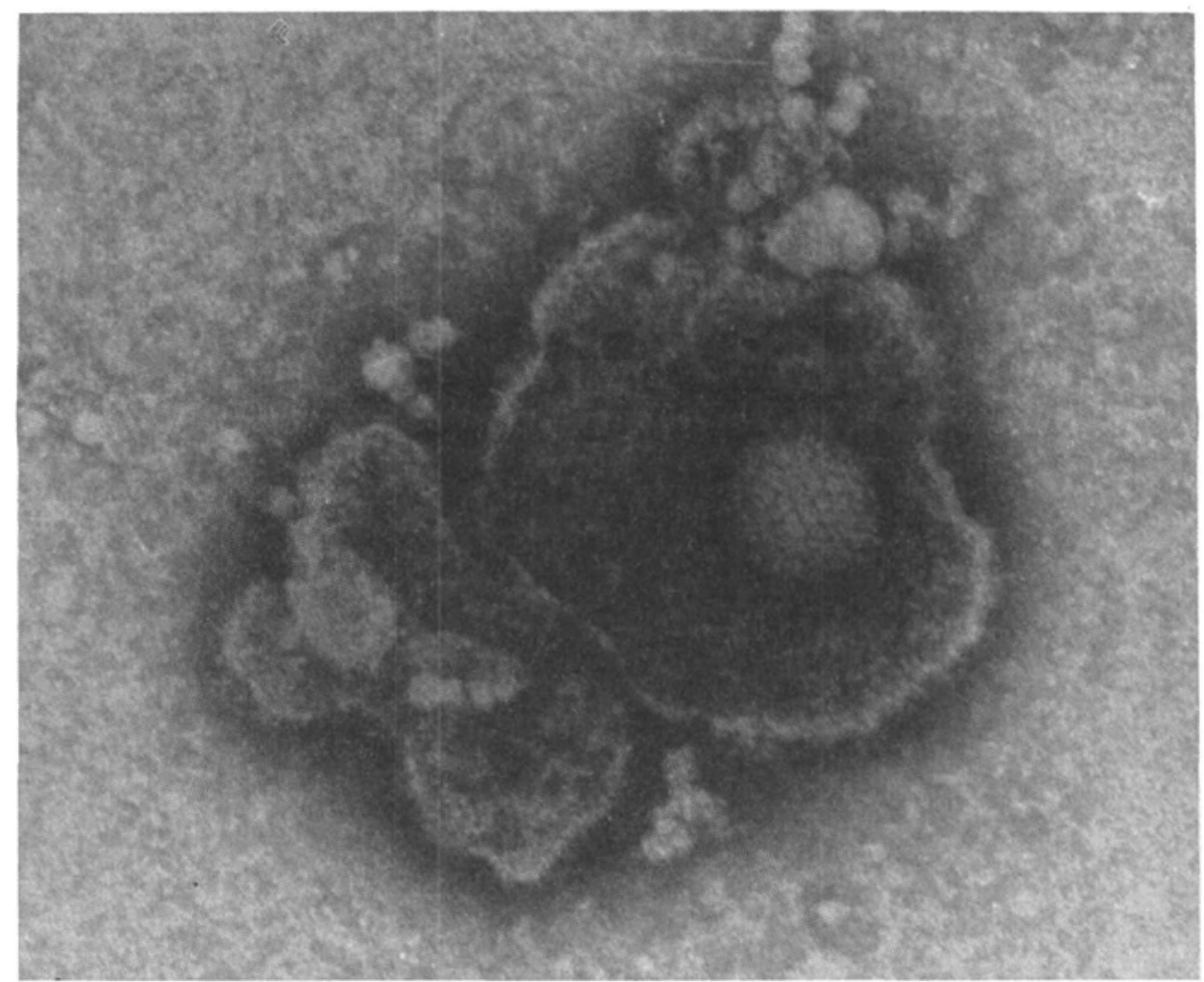

FIgUre 2. Electron micrograph showing virus in the exudate from the lesions. Courtesy of Miss N. Anderson, School of Hygiene, University of Toronto.

second week. Eighteen days after initial contact they became dry enough for the resident to resume duty in the operating room. Additional healing took place and was complete four weeks from the initial contact.

\section{Discussion}

The clinical picture described above resembles that recorded elsewhere in the medical literature. ${ }^{1,2,4}$ It is the second case diagnosed at Sunnybrook Hospital in a member of the anaesthetic staff. This infection has not been noted by the dental surgeons who staff this hospital, which is surprising unless they have built up a previous immunity.

Herpes virus is found in the respiratory secretions before and during the appearance of a typical "cold sore." Therefore it would seem that a patient with cold sores could readily transmit this virus to a susceptible person through oral or tracheotomy contact. Stern showed that suction catheters have been a source of the spread of this infection and that personnel engaged in the treatment of intensive care patients requiring suction fall prey to it. Further investigation showed that 49 per cent of nursing staff are without antibodies to herpes simplex 
virus and of the population at risk in an intensive care unit 16.5 per cent develop herpetic lesions. ${ }^{2}$

From the descriptions of this virus infection it is interesting to note that it rarely causes generalized symptoms. New vesicles may appear and coalesce, giving a multiloculated appearance. This may remain localized or spread by fresh crops of vesicles. Eventually a large subcuticular blister is formed that appears to be purulent; however, only serous or serosanguinous exudate is obtained. This last fact, plus the appearance of small vesicles beyond the edge of the lesion, may make clinical diagnosis possible. Positive diagnosis can be made only by viral studies. Treatment is mainly supportive. Secondary infection should be avoided by the use of dressings and freedom from exposure to contaminated areas. Antibiotics are not indicated unless secondary infection sets in. Pain relief with mild analgesics and rest of the affected part aid in the further comfort of the patient.

\section{Conclusion}

It is apparent from the mode of contact in this case report that considerable discomfort and lost time can be avoided by protecting one's hands when working in and about the mouth of infected patients even if the infections appear as inconsequential as herpes simplex.

\section{RÉSUMÉ}

Un malade, porteur de lésions d'herpès simple autour de la bouche, a transmis cette infection herpétique au doigt d'un résident en anesthésie. La lésion s'est développée et, au bout de onze jours, elle était violacée, gonflée et très douloureuse. Cette lésion a été ouverte et drainée; l'examen au microscope électronique du liquide de couleur jaunâtre a montré un grand nombre de particules ressemblant au virus de l'herpès simple (Fig. 2). Ce n'est que quatre semaines après le premier contact, que la guérison fut complète.

\section{REFERENCES}

1. Gavel.in, G. E. \& KNigur, C. R. Herpes Simplex Infection of the Finger. C.M.A.J. 21 : 366 (1965).

2. Stern, H.; Elick, S. D.; MLller, D. M.; \& Anderson, H. F. Herpetic Whitlow: A Form of Cross Infection in Hospitals. Lancet 2: 871 (1959).

3. Lindaren, K. M.; Douglas, G. R.; \& Cough, R. B. Significance of Herpesvirus Hominus in Respiratory Secretions of Man. New England J. Med. 278: 517 (1968).

4. KNyvet, A. F. Herpetic Whitlow. M. J. Australia 2: 601 (1966). 